\title{
GOVERNANCE AND PERFORMANCE OF MICROFINANCE INSTITUTIONS IN MEDITERRANEAN COUNTRIES
}

\author{
Ben Soltane Bassem \\ Sfax University, \\ Road of the airport $\mathrm{km} 4$ - BP $n^{\circ} 1088$ - 3018 Sfax, Tunisia \\ E-mail: bensoltane.bassem@laposte.net \\ Received 18 June 2007; accepted 10 September 2008
}

\begin{abstract}
This paper examines empirically the relation between governance mechanisms and the performance of EuroMediterranean microfinance institutions (MFIs) in terms of outreach and sustainability. Specifically, we found that performance-based compensation of managers is not associated with better performance of MFIs. The results identify trade-offs between MFIs outreach and sustainability depending on larger board size, and on higher proportion of unaffiliated directors. Moreover, the study shows that the more women there are on the board the better the performance, and reveals that external governance mechanisms help MFIs to achieve better financial performance. This study also allows us to distinguish other factors leading to better sustainability such as Regulation, and the use of individual lending methodology. However, the MFIs, active as NGOs, seem to be more consistent with their social mission than with their financial performance.
\end{abstract}

Keywords: microfinance institutions, governance, Euro-Mediterranean countries, performance, outreach, sustainability

\section{Introduction}

Microfinance is the provision of financial and nonfinancial services to the poor who are excluded from financial/credit markets because they are considered unbankable. Indeed, microfinance institutions have evolved primarily as a consequence of the efforts individuals and assistance agencies have committed to the idea of ensuring that the poor people have access to some form of credit. The majority of MFIs ${ }^{1}$ claim having a dual mission of reaching poor borrowers (outreach), and being financially sustainable (sustainability).

While the social goals of reaching the poorest and poverty alleviation are valid, financial sustainability has emerged as one of the core management and governance issues. The shrinking resources base for donor funds to support the increasing demand for grants and soft loans implies that MFIs will eventually have to support themselves (Ledgerwood 1999). However, their sustainability will focus on governance structures within the industry. Indeed, as Labie (2001) observes,

\footnotetext{
${ }^{1}$ Microfinance Institutions
}

in the last decade corporate governance principles have imposed themselves as the basic rules for any well-run company to follow. The trend has however transcended from traditional business companies but now is part of the globalization process often seen as a tool for standardizing the controlling vision for any major organization in the world. The drive towards Governance has been propelled by a number of factors, particularly the collapses of some of the major players in the Industry, the influx of private Equity and fall in donor funding.

Governance is about achieving corporate goals. The fundamental purpose of MFIs is to contribute to a country development. This involves reaching out to more clients, especially the poor (Helms 2006; Johnson et al. 2006). Not least but now growing in importance, especially among donors, is the requirement that MFIs achieve financial sustainability.

Microfinance practitioners assert that good governance is the key to a successful MFI (Campion 1998; Rock et al. 1998; Labie 2001; CGAP 2006; Helms 2006; UN 2006). In spite of these observations, only few studies have focused on governance and the examina- 
tion of the linkage of various governance mechanisms and performance (McGuire 1999). It seems relevant to examine closely the role of various governance mechanisms since MFIs managers control significant resources. Except the study of Hartarska (2005), and those of Mersland and Strøm (2007), and Cull et al. (2007), no more studies attempt to shed light on the link between governance and performance, especially in the Euro-Mediterranean countries, although it is a very active zone with a microfinance industry quite diverse $\left(\mathrm{NGO}^{2}, \mathrm{NBFI}^{3}\right.$, Bank) where actors should simultaneously pursue the most effective way of realizing their social objective while achieving superior levels of profitability.

While exploiting a recently conducted survey by the author in order to study the efficiency of MFIs in Mediterranean countries, the annual financial reports of the microfinance institutions, and other relevant information collected from Microfinance Information Exchange (MIX), this paper aims to investigate the link between governance and Euro-Mediterranean MFIs' performance in terms of outreach and sustainability since governance guides an institution in fulfilling its corporate mission and protects the institutions assets over time. As Rock et al. (1998) notes it is the key to guiding management in strategic issues and carrying out the agreed upon strategic plans. The empirical model explores the joint and individual effect of management compensation, board diversity, and external governance mechanisms on both MFI sustainability and the depth and breath of outreach while controlling for individual characteristics and, as well as country's specific factors. The results show that performancebased compensation does not improve performance. MFIs with larger boards seem to do better. More independent boards are more effective, however. Board diversity (Higher proportion of women) seems to ameliorate the outreach. External governance mechanisms especially auditing and regulation improve the financial sustainability.

The remainder of this paper is organized as follows. Section 2 deals with the research context. Section 3 briefly reviews the few related studies. Section 4 presents the conceptual framework as well as working hypothesis. Section 5 looks at data description and methodology. Section 6 discusses the empirical findings, and Section 7 draws conclusions emanating from the findings.

\footnotetext{
${ }^{2}$ Non-Governmental Organisation

${ }^{3}$ Non-Financial Bank Institution
}

\section{Microfinance in Mediterranean}

Experience throughout the world has proven that microfinance helps the poor to increase income, build their business, and secure their future by reducing their vulnerability to external shocks. Furthermore, microfinance is often a powerful tool for empowering the poor, especially women, to take charge of their economic well-being and those of their families.

The Euro-Mediterranean region consists of 21 countries. The microfinance industry in this zone is young with high growth potential. Currently, it is estimated that there are over sixty microfinance institutions (MFIs \& NGOs), and a potential of numerous other institutions producing credit to poor microentrepreneurs (Bassem 2008). The majority of these programs are south of the Mediterranean (Egypt, Jordan, Lebanon, Morocco, Palestine, Tunisia, and Syria). Programs also exist in Spain, France, Italy, Kosovo, Albania, Bosnia, and Croatia (Fig. 1).

Euro-Mediterranean MFIs aim to provide financial services to low-income households, even the extremely poor, in a participatory and non-paternalistic development approach to the great interest of the donor community, policy makers, development researchers and practitioners. According to the so-called "win-win" proposition MFIs should combine the socials goals, such as poverty alleviation and reaching poor households (outreach) with operational and financial selfsufficiency (sustainability) based on access to international financial markets independently from international development agencies. Therefore, MFIs should simultaneously pursue the most effective way of realizing their social objective while achieving superior levels of profitability.

The region's top MFIs are openly committed to best practice microfinance. In terms of depth of outreach, the sector has generally moved towards serving more and more of the poor clients. According to FEMIP and Sanabel, the Mediterranean represents a potential market for the microfinance with nearly 40 million customers, whereas currently only 9 million people profit from the financial assistance of the companies operating in this sector. The number of borrowers increased by more than $43 \%$ per annum between 2004 and 2006, against $20 \%$ on a worldwide scale, an indication that the sector as a whole is reaching more of the marginalized in the society. The region's top MFIs have proven also to have excellent leadership abilities, impressive outreach and growth, as well as a commitment to best practice microfinance. Furthermore, it is estimated that around $85 \%$ of the region's active clients are served by sustainable MFIs. 


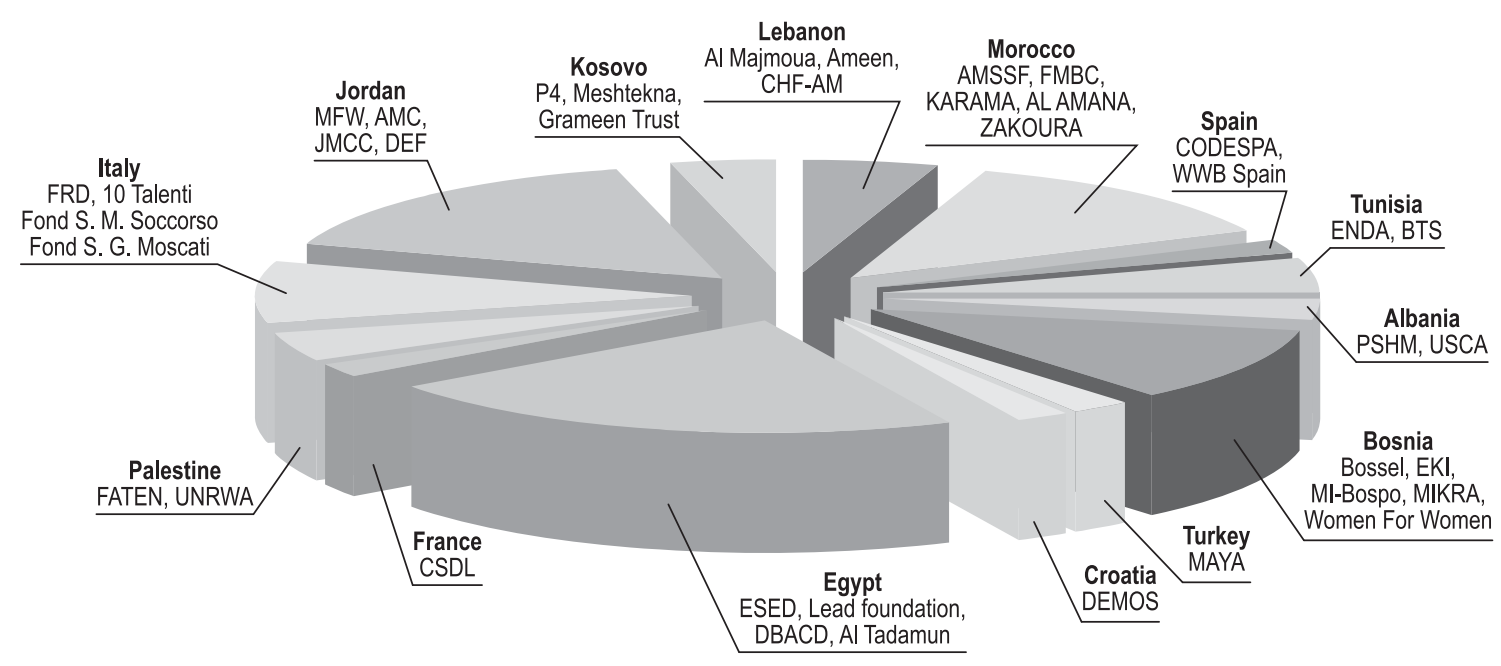

Fig. $\mathbf{1}^{4}$. MFIs delivering microcredit in the Mediterranean

\section{Literature review}

Governance in microfinance has been recognized to be an important issue. However, the biggest problem to microfinance practitioners has been balancing the dual mission of outreach and sustainability. The changing of microfinance environment has shown a move towards sustainability ultimately leading to governance issues as donor funds shrink and equity inflows increase in the microfinance sector. Microfinance institutions have therefore embraced boards and adopted principles of corporate governance to ensure their survival.

Investigating the link between good governance and the performance of MFIs in terms of outreach and sustainability is crucial since governance guides an institution in fulfilling its corporate mission and protects the institution assets over the time. However, there is a limited amount of academic studies dealing with this subject, partly due to the lack of data.

While using three surveys of rated and unrated East European MFIs from three random samples in the period 1998 to 2002, Hartarska (2005), investigates the relation between governance mechanisms and financial performance. Financial performance and outreach constitute dependant variable dimensions and governance mechanisms include board characteristics, managerial compensation, and external governance mechanisms such as rating, financial statements audited, and supervision. The author finds that performance-based compensation of managers is not associated with better performing MFIs; lower wages suggested for mission-driven organization worsen outreach. She also

\footnotetext{
${ }^{4}$ This figure quotes the most famous MFIs in the Mediterranean region.
}

identifies that a more independent board has the better ROA, but the board of employee directors gives lower financial performance and lower outreach. Finally, the author concludes that external governance mechanism seems to have a limited role in the study region.

In a recent study, Mersland and Strøm (2007), use a self-constructed global data set on MFIs spanning 57 countries collected from third-party rating agencies. The authors study the effect of board characteristics, ownership type, competition and regulations on the MFIs outreach to poor clients and its financial performance. They found that split roles of CEO Chairman, a female CEO, and competition are an important explanation. Moreover, the authors found that the larger board size decreased the average loan size, while individual guaranteed loan increased it. Finally, they conclude that there is no difference between non-profit organizations and shareholder firms in financial performance and outreach.

The third study was conducted by Cull et al. (2007) looking at MFIs financial performance and outreach as well, with a focus on lending methodology ${ }^{5}$, controlling for capital and labour cost as well as institutional features. While using the data from 124 rated MFIs, the authors found that MFIs which focus on providing loans to individuals perform better in terms of profitability. Yet, the fraction of poor borrowers and female borrowers in the loan portfolio of these MFIs is lower than for MFIs which focus on lending to groups. The study suggests also that individual-based MFIs,

\footnotetext{
${ }^{5}$ Lending methodology refers to the way loans are given. Individual loans, group loans, and village banks (which are bigger groups that often have wider objectives than to serve as a guarantee mechanism only) are the categories used.
} 
especially if they grow larger, focus increasingly on wealthier clients, a phenomenon termed as "mission drift". This mission drift does not occur as strongly for the group-based MFIs. However, no governance variables, such as board characteristics or ownership type are taken into consideration.

The limited academic investigation into the link between governance mechanisms and performance of MFIs in terms of outreach and sustainability, and the fact that other governance mechanisms such as the proportion of women in the board remain unexplored justify the importance of a similar study in the EuroMediterranean zone, characterized by a very active and quite diverse microfinance industry, that complete former studies.

\section{Conceptual framework and working hypothesis}

While focusing on the microfinance field, the governance can be defined as the process of guiding an institution to achieve its objectives while protecting its assets. It refers to the mechanisms through which donors, equity, investors, and other providers of funds ensure themselves that their funds will be used according to the intended purposes (Hatarska 2005). The presence of these control mechanisms is crucial either to align the interests of managers and providers of funds since they may have diverting preferences and objectives, or to monitor the performance of managers to ensure that they use their delegated power to generate the highest possible returns for the providers of funds. This notion comes from the agency perspective. It found its origins in the work of Jensen and Meckling (1976) who assimilate the firm to a node of contracts. The explanatory model of the structures of financing and shareholding is founded on the assumption of asymmetry of information and conflicts of interests between managers and providers of funds. According to Jensen and Meckling (1976), agency relationship is a contract under which "one or more persons (principal) engage another person (agent) to perform some service on their behalf, which involves delegating some decision-making authority to the agent" ${ }^{6}$. In this case the relation of agency will relate the principal (owner) and his agent (manager), this last being engaged to serve the interests of the first. From these relations the concept of agency costs emanates, costs which result from the potentially opportunist character of the actors (moral hazard) and information asymmetry between the contracting parties

\footnotetext{
${ }^{6}$ Jensen, M. C.; Meckling, W. H. 1976. Theory of the firm: managerial behaviour, agency costs, and ownership structure, Journal of Financial Economics 3: 305-350.
}

(adverse selection). These agency costs represent the loss in value compared to an ideal situation where there is no information asymmetry and conflict of interests. According to the theorist of agency, an organisation is considered efficient if it minimises the agency costs. This purpose can be intended through an effective governance mechanism.

According to Keasey et al. (1997), the most important features of an effective governance framework are ownership structure (including institutional and managerial ownership), CEO (manager) and director (board member) remuneration, board structure (size and composition), auditing, information disclosure, and the market for corporate control. Usually, research literature related to this field use partial measures. In other words, governance studies treat separately the impact of each variable such as compensation, board size, independence and diversity, and external market forces on firm performance. However, since latest studies (Hermalin and Weisbach 2003) identify the complementarities, and the correlation between these mechanisms, this study will investigate the impact of the majority of these mechanisms excluding ownership due to lack of data on ownership structure.

The most important attribute that distinguishes microfinance institutions from others is what has come to be called its dual mission of balancing a social agenda or social impact with its financial objectives. The MFI combines a social development mission (provision of financial services to the lowest income population possible), with financial objectives that drives the institution to achieve self-sufficiency and thereby accomplish sustained service delivery without dependence on subsidies. These dual objectives (social: outreach, and financial: sustainability) make difficult the study of governance of MFIs, especially with their different types: Non-profit, Non-Governmental Organizations (NGOs), For-profit Microfinance Institutions, Credit Unions. This challenge is surmounted by formulating and testing hypothesis based on insights from the literature on corporate governance, former studies (Hartarska 2005; Mersland and Strøm 2007; Cull et al. 2007), governance in banks and in Non-profit organizations, and by estimating the impact of the governance mechanisms on both sustainability and outreach.

\subsection{Internal governance mechanisms}

The incentives of top management have been characterized as an important mechanism of corporate governance as it ensures the alignment of the management with the shareholders interest (John et al.2004). In other words, it serves as a mechanism for resolving the conflict of interests between the managers and shareholders. 
Brick et al. (2006) highlighted that director compensation should also affect performance of a firm. With regard to banking institutions, higher-powered incentives may encourage managers to take higher risks at the expense of depositors, who would suffer if the institution fails; thus, low pay-performance sensitivity is suggested (John, T.A. and John, K. 1993). In fact, it is proved by Adams and Mehran (2003), Houston and James (1995), John and Qian (2003), that pay-performance sensitivity in banking is lower than in other industries.

Since in non-profit firm there is a growing problem of informational asymmetry between clients and managers (i.e., managers possess much crucial information about the product), it seems that the fixed management salaries is the best choice for mission-driven organizations (Easley and O'Hara 1998). With the fixed salaries, the managers, indifferent between telling the truth or lying, will find it to their benefit to tell the truth. Therefore, if the client and donors find the information provided by non-profit managers more credible, the firm will be better-funded and better-performed.

Hypothesis 1. MFIs whose manager receives a fixed salary will not perform worse than MFIs whose managers receive performance based remuneration.

Most guidelines recognize that the board of directors is the focal point for corporate governance. The composition and structure of the board have a direct bearing on corporate governance. Board of directors is designated for the purpose of ensuring the alignment of the firm activities with its specified objectives. The board has the duty for making sure that the top managers are behaving in a way that will provide the optimal value for shareholders (Coles et al. 2001).

There is a view that larger boards are better for corporate performance because they have a range of expertise to help to make better decisions, and are harder for a powerful CEO to dominate. However, recent thinking has leaned towards smaller boards. Jensen (1993), Lipton and Lorsch (1992) argue that large boards are less effective and are easier for a CEO to control. When the board gets too big, it becomes difficult to co-ordinate and process problems. Smaller boards also reduce the possibility of free riding by individual directors, and increase their decision taking processes. Empirical research supports this. For example, Yermack (1996) documents that for large U.S. industrial corporations, the market values firms with smaller boards more highly. Eisenberg et al. (1998) also find negative correlation between the board size and profitability when using a sample of small and mid-size Finnish firms. In Ghana, it has been identified that small board size enhances the performance of MFIs (Kyereboah-Coleman and Biekpe 2005). Mak and Yuanto (2003) echo the above findings in firms listed in Singapore and Malaysia when they found that firm valuation is highest when the board has five directors, a number considered relatively small in those markets. In a Nigerian study, Sanda et al. (2003) found that, firm performance is positively related with small, as opposed to large boards.

Hypothesis 2. Board size should have an inverse correlation with MFIs performance

The third common monitoring mechanism advocated by the agency perspective is the board composed of a majority of independent directors. These non-executive or "outside" directors are believed to provide superior benefits to the firm as a result of their independence from firm management. Under this organizational design, conflicts of interest can be avoided and executive leaders can be evaluated more objectively.

The literature suggested that increases in the proportion of outside directors on the board should increase firm performance as they are more effective monitors of managers (Adams and Mehran 2003). The proportion of the outside directors can be measured in terms of the ratio of outside directors to board size. The positive aspect of having board independence was evidenced in the study by Byrd et al. 2001, that highlighted the survival of firms in the thrift crisis due to greater proportion of independent directors on the board. Kyereboah-Coleman and Biekpe (2005) also found a positive relationship between the proportion of outside board members and performance of MFIs in Ghana.

Hypothesis 3. MFIs performance will be affected positively by the proportion of non-affiliated outsiders on the board.

Corporate governance literature argues that board diversity in terms of women and minority representation is potentially positively related to firm performance. Board diversity promotes a better understanding of the marketplace, increases creativity and innovation, produces more effective problem solving, enhances the effectiveness of corporate leadership, and promotes effective global relationships (Robinson and Dechant 1997). Fondas and Sassalos (2000) argue that diversity in board composition via greater female representation will lead to improved board governance and top management control. In microfinance, the study of Kyereboah-Coleman (2006) shows that having women in CEOs on MFI boards enhance performance, and also the more women there are on the board, the better the performance. Furthermore, having a high fraction of women in the board would help the MFI understand its customers better so as to separate the good risk from the bad (Mersland and Strøm, 2007).

Hypothesis 4. Board diversification and the presence of women will lead to a better performance of MFI. 
Another principle of effective bank supervision is effective internal audit. Internal audit helps to identify problem areas and to avoid major collapse. The internal board auditor provides independent, objective assessment of the appropriateness of the organization's internal governance structure and the operating effectiveness of specific governance activities. Reporting of all internal audit reports in the accurate and timely manner is essential for evaluation of the institution's status and need for any change in strategy. Policy papers for MFIs stress the importance of internal audit and recommend that the internal auditor reports directly to the MFI board (Steinwand 2000).

Hypothesis 5. MFI allowing their internal auditors to report directly to the board should show higher financial performance.

\subsection{External governance mechanisms}

The external governance mechanism can be implemented as a result of the failure or the weakness of internal governance mechanisms. In the microfinance industry donors and creditors are increasingly relying on information from audited financial statement and rating agencies (Hartarska 2005). These external governance mechanisms are an important mechanism that provides depositors, creditors and shareholders with credible assurances that they will refrain from fraudulent activities. In other words, it reduces informational asymmetries between the different stakeholders and the firm (Healy, Palepu 2001).

Audited financial statements are an important tool for the assessment of MFIs by regulators and capital markets. They form an important part of the effective corporate governance. The auditor's role is to provide a disinterested and objective view whether the financial statements on the MFI are in line with generally accepted accounting standards. It is a means to ensure potential investors and donors that MFI complies with the accounting practices and managers do not misrepresent financial information.

Hypothesis 6. MFIs with financial statement audited achieve better performance than MFIs without financial statement audited.

According to Hartarska (2005), in the absence of developed equity and debt market, donors and investors rely on independent evaluation of MFIs performance. A MFIs rating reflects a rating agency's opinion of entity's overall creditworthiness and its capacity to satisfy its financial obligations. The raters evaluate objectively and independently the corporate governance in MFI and rank it on a relative rating scale that would facilitate comparison. Unlike typical rating agencies that rate the riskiness of issued debt, microfinance rating agencies rate the overall performance of the MFI in terms of outreach and sustainability.

\section{Hypothesis 7. Rating helps MFIs to achieve better} results

Many MFIs around the world operating as NGOs have increased their assets, reorganized, and transformed into regulated entities that can capture savings deposits. A regulated MFI has more chance to earn customer trust, and, by the way, to have a higher financial performance. Hence, regulation is crucial for microfinance sector development since it affects MFI performance by changing the internal rule of the organization. It implies the access to an important and low-cost funding source through the right to mobilise savings. Due to this effect, the MFI wins the opportunity to increase the number of clients, but also to increase average loan amounts for existing borrowers. Moreover, if demands to fulfill regulatory requirements divert attention away from serving the poor, and hold back innovation in lending technology that has been the driving force behind MFIs' ability to serve even poorer borrowers, regulatory involvement will lead to "mission-drift" (Hartarska 2007). Therefore, the effects upon depth and breadth in outreach may be uncertain as well, either upon depth or breadth, or a combination of the two (Mersland, Strom 2007).

Hypothesis 8. Regulation may guide the MFIs to fulfill better sustainability, but not to achieve better outreach.

\section{Data and methodological issues}

Data for this study are obtained from various sources. The major part comes from the survey conducted by the author in 2006 in order to test the efficiency of microfinance institutions in Mediterranean (Bassem 2008). The performance variables and some governance variables are also obtained from the annual financial reports of the microfinance institutions collected from Microfinance Information Exchange (MIX), a nongovernmental organization whose object is to promote the exchange of information on the microfinance sector around the world ${ }^{7}$. All this information is updated and

\footnotetext{
${ }^{7}$ Informations on the MIX are available on the Web site www. themix.org. The data bases on the MFIs are accessible by the mixmarket, an online data base accessible from the MIX site. Mix Market, known formerly under the name of "Virtual Market of Microfinance" was initiated jointly by the UNCTAD and the Government of Luxembourg. In 2001, it was taken in charge by the Consultative Group to Assist the Poor (CGAP), a consortium of backers which works for the development of Microfinance in the world.
} 
completed by a questionnaire dealing fundamentally with detailed questions on governance addressed to the MFIs in the region. The response rate was $58 \%$ with 40 institutions.

A special questionnaire was also addressed to the Mediterranean microfinance institutions that don't figure in the MIX MARKET data base. The response rate for these MFIs was weak and near $20 \%$, with four institutions. Due to missing data, only two institutions are taken into account. The final sample comprises 42 institutions working in 21 countries. Our sample is quite representative of the Mediterranean microfinance industry as well as of the governance mechanisms and the performance of MFIs in the region.

Following Hartarska (2005) works, our empirical model used to test the hypotheses includes five major potential groups of determinants and takes the form:

$P_{i j t}=\alpha_{0}+\beta_{1} S_{i j t}+\beta_{2} M_{i j t}+\beta_{3} B_{i j t}+\beta_{4} E G_{i j t-1}+\beta_{5} M_{j t}+\varepsilon_{i j t}$,

where $P_{i j t}$ is a performance variable for MFI $i$, in country $j$, at time $t ; S_{i j t}$ are MFI specific variables; $M_{i j t}$ are management specific variables; $B_{i j t}$ are board-specific variables, $E G_{i j t-1}$ are external governance mechanisms; and $M I_{j t}$ are the country-specific macroeconomic variables. It is crucial to mention at this level that our choice of a single-equation model is supported by the hypothesis that various governance mechanisms are endogenously determined is not always supported by empirical evidence ${ }^{8}$.

Since MFIs are special institutions having a dual mission, their performance is measured in terms of outreach and sustainability (Table 1). Outreach is measured in breath and depth. Breath of outreach (NAB) is the logarithm of active borrowers, depth of outreach $\left(\mathrm{DEPTH}^{9}\right)$ is the average loan size on GDP per capita. Sustainability is measured by return on assets (ROA) which is a standard finance literature measure of performance, and by operational self-sufficiency (OSS). This variable measures how well the MFI can cover its costs through operating revenues.

MFI specific variables $\left(S_{i j t}\right)$ are: MFI size measured by the logarithm of total assets; MFI age measured in

\footnotetext{
${ }^{8}$ Although the properties of the Hausman test for endogeneity are not well understood in small samples, this test does not indicate that the individual governance mechanisms are endogenous (Wooldridge 2002).

${ }^{9}$ The higher the value of DEPTH, the less poor clients are being served. Therefore from a poverty-alleviation perspective, a smaller value of this variable is preferred.
}

Table 1. Definitions of dependent variables used in analyses

\begin{tabular}{ll}
\hline Variable & Explanation \\
\hline $\begin{array}{l}\text { Social Performance: } \\
\text { Outreach }\end{array}$ & \\
\hline $\boldsymbol{N A B}$ & $\begin{array}{l}\text { Logarithm of the number } \\
\text { of current borrowers }\end{array}$ \\
\hline $\boldsymbol{D E P T H}$ & $\begin{array}{l}\text { The average loan size on } \\
\text { GDP per capita }\end{array}$ \\
\hline
\end{tabular}

Financial Performance:

Sustainability

\begin{tabular}{ll}
\hline $\boldsymbol{R O A}$ & Return On Assets \\
\hline $\boldsymbol{O S S}$ & Operational Self-Sufficiency \\
\hline
\end{tabular}

years since commencement, and MFI type measured by three dummies (NGO, Non-bank Financial Institution, and bank). Since further studies (Navajas et al. 2003) show that the type of lending methodology used influences the success of these organizations, our study includes a variable Individual which is a dummy that takes the value of one if the MFI used individual lending technology.

Variables built-in $M_{i j t}$ (Table 2) are: Fixed-wage, which is a dummy for pay not based on performance, $E x$ perience that is used as proxy for the manger's quality and is measured by the years of work experience. The board-specific variables $B_{i j t}$ contain: Board-size, measured by the number of board members; Independent, measured as the proportion of non-affiliated board members; Women, measured as the proportion of women on the board; Internal Board Auditor is a dummy variable that takes the value of one if there was an internal auditor with direct access to the board.

The variables included in $E G_{i j t-1}$ are: Regulation, which is a dummy that takes the value of one if the MFI was supervised by the central bank or other bank supervisory agency; Rated is a variable that indicates whether the MFI was subject to independent evaluation or rating by an outside organization; Audited is a dummy that also takes the value of one if there was an audited financial statement in the year $\mathrm{t}-1$.

Since MFIs are issued from north and south of the Mediterranean, the dissimilarity in economic conditions across countries are controlled by the size of the economy (Economy size), measured by the logarithm of a country's GDP, and by the average inflation rate (Inflation), measured by the average consumer price 
Table 2. Definitions of independent variables used in analyses

\begin{tabular}{|c|c|}
\hline Variable & Explanation \\
\hline Fixed-wage & A dummy being one if the manager receives a fixed salary \\
\hline Experience & The number of years of experience of the manager \\
\hline Board-size & Number of board members \\
\hline Independent & $\begin{array}{l}\text { The proportion of voting board members who do not have an affiliation with any of the } \\
\text { stakeholders of the MFI }\end{array}$ \\
\hline Women & The proportion of the women on the board \\
\hline Internal board auditor & A dummy being one if internal board auditor reports directly to the board \\
\hline Audited & A dummy that equals one if the financial statement of the MFI is audited and zero otherwise \\
\hline Rated & $\begin{array}{l}\text { A dummy that equals one if the MFI is rated by a specialized MFI rating agency and zero } \\
\text { otherwise }\end{array}$ \\
\hline Regulation & A dummy being one if the MFI is regulated by banking authorities \\
\hline Individual & A dummy that equals one if the MFI used individual lending methodology and zero otherwise \\
\hline MFI age & Number of years since the commencement \\
\hline MFI size & Logarithm of the total assets of the MFI \\
\hline $\mathrm{NGO}$ & The MFI is an NGO \\
\hline NBFI & The MFI is an non-financial bank institution \\
\hline Bank & The MFI is an bank \\
\hline Inflation & Average annualized consumer price index \\
\hline Economy size & Logarithm of total GDP (Gross Domestic Product of the country) for the year $t$ \\
\hline
\end{tabular}

index. These variables are issued from the World Bank Development Indicators. We wanted also to build a variable that would take account of the institutional differences between countries but we did not find an adequate measure.

The descriptive statistics for this study are shown in Table 3. Notably, we have complete records of data for only 42 institutions. The performances of Microfinance Institutions are widely spread. On average, the MFIs recorded a return on assets of 5,935\%. While the minimum was $-7.58 \%$, the maximum performance was 33\% indicating a widely spread performance. Similarly, the studied MFIs have on average an Operational Self-Sufficiency of $85.41 \%$ with respectively a minimum and a maximum of $20.345 \%$ and $143.33 \%$. With regard to the DEPTH, the average value of relatively weak 220 indicate that the poor borrowers are very well served.

On average, the MFIs managers have 8.4 years of experience and $82.4 \%$ of these managers are receiving a
Fixed-wage. On average, 5 persons serve on the board of an MFI and a standard deviation of 3,32 coupled with a maximum board size of 16 members and a minimum board size of 4 members suggest that these boards are widely dispersed. The unaffiliated directors represent on average $45 \%$ of the board members. The descriptive statistics also indicate that on average 39\% of all boards are made up of women.

In our sample, around half of the MFIs have an internal auditor reporting directly to the board. Moreover, $81 \%$ of the MFIs studied have their financial statement audited and $37 \%$ of the MFIs forming the sample are rated. The result also shows that $42 \%$ of the institutions are regulated, and the individual lending technology constitutes $73 \%$ of the cases. The average age standing for the MFI is about 3 years. The NGOs represent $59 \%$ of our sample, however, the NBFI and Bank represent respectively $17 \%$ and $9 \%$ of the sample. Finally, the average inflation rate in all the countries subject to the study is about $16 \%$. 
Table 3. Descriptive statistics $(\mathrm{N}=42)$

\begin{tabular}{|c|c|c|c|c|}
\hline Variable & Mean & Standard Deviation & Min & Max \\
\hline ROA & 5.935 & 23.12 & -7.58 & 33 \\
\hline OSS & 85.41 & 63.2 & 20.345 & 143.33 \\
\hline NAB & 8.238 & 45.11 & 2.34 & 45.23 \\
\hline DEPTH & 220 & 143 & 111 & 654 \\
\hline Fixed-wage & 0.824 & 0.578 & 0 & 1 \\
\hline Experience & 8.4 & 16.12 & 2 & 11 \\
\hline Board-size & 5.82 & 3.32 & 4 & 16 \\
\hline Independent & 0.457 & 0.245 & 0 & 0.213 \\
\hline Women & 0.398 & 0.367 & 0 & 0.453 \\
\hline Internal board auditor & 0.478 & 0.532 & 0 & 1 \\
\hline Audited & 0.812 & 0.634 & 0 & 1 \\
\hline Rated & 0.376 & 0.512 & 0 & 1 \\
\hline Regulation & 0.423 & 0.675 & 0 & 1 \\
\hline Individual & 0.732 & 0.479 & 0 & 1 \\
\hline MFI age & 3.254 & 2.349 & 4 & 17 \\
\hline MFI size & 17.634 & 2.115 & 7.311 & 23.546 \\
\hline NGO & 0.598 & 0.463 & - & - \\
\hline NBFI & 0.178 & 0.234 & - & - \\
\hline Bank & 0.098 & 0.127 & - & - \\
\hline Inflation & 0.164 & 0.254 & 0.023 & 0.328 \\
\hline Economy size & 19.34 & 2.278 & 12.432 & 34.897 \\
\hline
\end{tabular}

Source: Authors' estimates

\section{Discussion of findings}

As shown in Table 4 dealing with the estimation of the impact on sustainability and outreach, our first hypothesis stipulating that the remuneration system (performance-based compensation or fixed salary) is confirmed. The coefficient of Fixed-wage is not significant in any of the specifications. This result confirms former findings, such as Hartarska (2005) and can be attributed to the fact that MFIs managers may have not reacted to performance-based compensation offered during the study period.

Managerial qualifications as shown by the positive and significant sign of Experience in the OSS and NAB regressions as well as the enviable negative and significant coefficient in the DEPTH indicate that the acquired experience allows MFIs managers to reach poor borrowers and produce better sustainability.
Board size is rather positively related to ROA, OSS, and NAB suggesting to the contrary that MFIs with larger boards seem to do better. The results reduplicate our second hypothesis and confirm studies that support the view that larger boards are better for corporate performance since members have a range of expertise to help to make better decision, and are harder for powerful CEO to dominate. This is in sharp contrast to finding by Jensen (1993), Lipton and Lorsch (1992), Eisenberg et al. (1998), Sanda et al. (2003); however, it confirms the finding of Kyereboah-Coleman (2006). An important result of this study is the support for the third hypothesis that MFIs with a higher proportion of unaffiliated directors had better sustainability (ROA \& OSS) and also reach poor borrowers. This result confirms previous works: Hartarska (2005), and indicates that MFIs can also benefit from more independent boards. 
Table 4. Regression Results of sustainability and outreach

\begin{tabular}{|c|c|c|c|c|}
\hline & \multicolumn{2}{|c|}{ Sustainability } & \multicolumn{2}{|c|}{ Outreach } \\
\hline & ROA & OSS & NAB & DEPTH \\
\hline Fixed-wage & $\begin{array}{c}2.76 \\
(0.23)\end{array}$ & $\begin{array}{c}1.38 \\
(1.02)\end{array}$ & $\begin{array}{l}-0.157 \\
(-0.47)\end{array}$ & $\begin{array}{l}-0.356 \\
(-0.36)\end{array}$ \\
\hline Experience & $\begin{array}{c}0.09 \\
(0.044)\end{array}$ & $\begin{array}{c}1.528 \\
(9.72)^{* * *}\end{array}$ & $\begin{array}{c}0.064 \\
(2.65)^{* * *}\end{array}$ & $\begin{array}{c}-0.024 \\
(3.22)^{* * *}\end{array}$ \\
\hline Board-size & $\begin{array}{c}0.1927 \\
(4.23)^{* *}\end{array}$ & $\begin{array}{c}0.1923 \\
(4.23)^{* *}\end{array}$ & $\begin{array}{c}0.079 \\
(2.74)^{* * *}\end{array}$ & $\begin{array}{c}-0.028 \\
(0.61)\end{array}$ \\
\hline Independent & $\begin{array}{c}0.081 \\
(2.21)^{* *}\end{array}$ & $\begin{array}{c}0.044 * * \\
(1.54)\end{array}$ & $\begin{array}{l}1.528 \\
0.034\end{array}$ & $\begin{array}{l}-0.029 \\
(1.93)^{*}\end{array}$ \\
\hline Women & $\begin{array}{l}0.234 \\
(2.18)\end{array}$ & $\begin{array}{l}0.081 \\
(3.18)\end{array}$ & $\begin{array}{c}1.224 * * \\
(0,09)\end{array}$ & $\begin{array}{c}-0.567 * * \\
(1.11)\end{array}$ \\
\hline Internal board auditor & $\begin{array}{c}0.94 \\
(1.21)\end{array}$ & $\begin{array}{l}0.061 \\
(0.42)\end{array}$ & $\begin{array}{c}2.34 \\
(2.43)\end{array}$ & $\begin{array}{c}0.34 \\
(0.09)\end{array}$ \\
\hline Audit & $\begin{array}{c}1.919 * * * \\
(0.203)\end{array}$ & $\begin{array}{c}0.006 * * \\
(0.009)\end{array}$ & $\begin{array}{c}0.003 \\
(0.002)\end{array}$ & $\begin{array}{l}-0.182 \\
(0.187)\end{array}$ \\
\hline Rating & $\begin{array}{c}0.006 \\
(0.009)\end{array}$ & $\begin{array}{c}0.033 \\
(0.132)\end{array}$ & $\begin{array}{c}0.138 \\
(0.071)\end{array}$ & $\begin{array}{l}-0.212 \\
(0.192)\end{array}$ \\
\hline Regulation & $\begin{array}{c}0.776 * * * \\
(0.161)\end{array}$ & $\begin{array}{c}0.002 * * \\
(0.013)\end{array}$ & $\begin{array}{l}-0.013 \\
(0.054)\end{array}$ & $\begin{array}{c}0.008 \\
(0.013)\end{array}$ \\
\hline Individual & $\begin{array}{c}0.348 * * * \\
(0.075)\end{array}$ & $\begin{array}{c}0.009 \\
(0.143)\end{array}$ & $\begin{array}{c}0.024 \\
(0.055)\end{array}$ & $\begin{array}{l}-0.061 \\
(0.055)\end{array}$ \\
\hline MFI age & $\begin{array}{c}0.174 * * \\
(0.152)\end{array}$ & $\begin{array}{c}0.168 * * \\
(0.072)\end{array}$ & $\begin{array}{c}0.002 * * * \\
(0.013)\end{array}$ & $\begin{array}{c}-0.018 * * \\
(0.137)\end{array}$ \\
\hline MFI size & $\begin{array}{l}0.033^{*} \\
(0.132)\end{array}$ & $\begin{array}{c}0,234 * * \\
(4.32)\end{array}$ & $\begin{array}{c}0.012 * * \\
(0.13)\end{array}$ & $\begin{array}{c}-0.125^{*} \\
(0.432)\end{array}$ \\
\hline $\mathrm{NGO}$ & $\begin{array}{l}-0.001 \\
(0.004)\end{array}$ & $\begin{array}{l}-0.109 \\
(0.084)\end{array}$ & $\begin{array}{c}0.003 * * \\
(0.005)\end{array}$ & $\begin{array}{c}-0.003 * * * \\
(0.005)\end{array}$ \\
\hline NBFI & $\begin{array}{c}0.059 \\
(0.013)\end{array}$ & $\begin{array}{c}0.417 \\
(0.187)\end{array}$ & $\begin{array}{c}0.003 \\
(0.009)\end{array}$ & $\begin{array}{l}-0.278 \\
(0.162)\end{array}$ \\
\hline Bank & $\begin{array}{c}0.19 \\
(0.124)\end{array}$ & $\begin{array}{c}0.271 \\
(0.238)\end{array}$ & $\begin{array}{c}0.102 \\
(0.076)\end{array}$ & $\begin{array}{c}0.023 \\
(0.301)\end{array}$ \\
\hline Inflation & $\begin{array}{c}-0.196 * * \\
(0.025)\end{array}$ & $\begin{array}{c}-0.020 * * \\
(0.009)\end{array}$ & $\begin{array}{c}-11.915 \\
(1.814)\end{array}$ & $\begin{array}{l}-0.306 \\
(0.059)\end{array}$ \\
\hline Economy size & $\begin{array}{l}-0.028 \\
(0.008)\end{array}$ & $\begin{array}{c}0.148 \\
(0.172)\end{array}$ & $\begin{array}{c}0.007 * * \\
(0.002)\end{array}$ & $\begin{array}{c}-0.006^{* *} \\
(0.002)\end{array}$ \\
\hline Constant & $\begin{array}{c}-3.2708 * * \\
(-3.33)\end{array}$ & $\begin{array}{c}-3.2268 * * \\
(-3.31)\end{array}$ & $\begin{array}{c}0.2789 \\
(2.11)\end{array}$ & $\begin{array}{c}0.2962 * * \\
(2.09)\end{array}$ \\
\hline Number of observations & 42 & 42 & 42 & 42 \\
\hline World Statistics & 79.23 & 83.34 & 92.12 & 89.37 \\
\hline Log pseudo-likelihood & -168.93505 & -146.57205 & -123.87643 & -178.34896 \\
\hline Pseudo R2 & 42 & 42 & 42 & 42 \\
\hline
\end{tabular}

Absolute value of $t$-statistics in parentheses

*Significant at 10\% level, ** Significant at 5\% level, *** Significant at $1 \%$ level 
The results of the study confirm partially the fourth hypothesis and show that board diversity (higher proportion of women) improves social performance. This is consistent with recent thinking and discussions which point to the fact that governance reforms have been geared towards the importance of gender diversity, especially in the boardroom, and that the issue of gender diversity is central and could enhance board effectiveness by tapping broader talent pools for their directors resulting in the more diverse board having better relations with other stakeholders such as customers, suppliers, and employees (Ellis, Keys 2003) which inevitably translate into performance and firm value (Kyereboah-Coleman 2006).

Our fifth hypothesis is not confirmed by the empirical results. Although the internal auditor reporting to the board is the way to reach board governance with information relative to internal firm governance, the results indicate that the internal board editor seems not to have any significant influence on MFIs performance. A similar result was found by Mersland and Strøm (2007).

Although microfinance rating agencies rate the overall performance of the MFIs in terms of outreach and sustainability, the empirical results show that this variable does not have any significant influence on MFIs performance. In addition, the study reveals that MFIs having their financial statement audited achieve better sustainability. These MFIs comply with accounting practices and are able to reach higher levels of financial performance.

Regulated MFIs do not reach more borrowers but according to the results in Table 4, have significant and positive ROA \& OSS. Although this result is diverse from past studies which did not find any relation between these two dimensions: Mersland and Strøm (2007), or found a weak relation: Hartarska (2005), it brings the evidence that regulation may assure customers that they are treated fairly and this could lead to more business and better financial performance.

Results indicate that the lending technology improves considerably the financial performance of the MFIs. This result can be attributed to the fact that the cost argument is more important than the repayment argument for group lending or village bank. The supposed efficiency in group lending does not hold in Mersland and Strøm (2007). From another point of view, it can be justified by the new tendency toward the individual microlending (Armendariz de Aghion, Morduch 2005), since this methodology becomes highly recommended (Armendariz de Aghion, Morduch 2000). This study confirms well the study of Cull et al. (2007).
In conformity with the theory and former studies such as Kyereboah-Coleman (2006), the age of the firm as proxy for reputation impacts positively on performance likewise the size of the MFI. Expectedly, the size of MFI has a significant positive impact on performance. This may be due to the fact that a large firm has the ability to accommodate risk and to enhance productivity through diversification of products and services. The study shows that NGOs are more efficient than NBFI and show better social performance by reaching the poor. It becomes clear that NGOs are more consistent with their social mission than with their financial performance. The results reveal also the significance of controlling for crosscountry differences. The level of inflation affects negatively the sustainability of MFIs. Comparable results were found by Hartarska (2005), in Central and Eastern Europe and the Newly Independent States. Finally, the study suggests that the economy of big size affects outreach.

\section{Conclusions and recommendations}

This paper tests empirically the relationship between corporate governance and Euro-Mediterranean MFIs performance in terms of outreach and sustainability. While using data from a self-conducted survey as well as from the annual financial reports and from the Mix Market, the study examines the impact of management remuneration, board independence and diversity, internal auditor reporting directly to the board, external governance mechanisms of control, and MFIs and countries' specifications. Results indicate that not all known governance mechanisms affect performance and in addition, different factors have the differential effect on outreach and sustainability.

The study shows that explicit and implicit incentives schemes such as compensation, perks, etc. become less powerful and less able to motivate managers (Dewatripont, Tirole 1994). Results also show that larger boards are better for MFIs performance since members have a range of expertise to help to make better decision and are harder for powerful CEO to dominate. Moreover, the study reveals that microfinance boards with larger proportions of unaffiliated directors achieve better results. Thus, independence of the microfinance board should be encouraged.

The fundamental result of this study is that board diversity (higher proportion of women) enhances performance and again the more women there are on the board, the better the performance. Thus board diversity is paramount for enhanced performance of microfinance institution. 
Having financial statement audited, and being rated by international agencies is synonym to a better financial performance. It seems that external governance mechanisms help MFIs to reach their financial performance. This study allows us to distinguish other factors leading also to a better sustainability such as Regulation and the use of individual lending methodology. However, the MFIs type (NGO) seems to be more consistent with their social mission than with their financial performance. The microfinance institutions characteristics such as age and size affect positively the performance, nevertheless, the level of inflation has a negative impact on the sustainability of MFIs.

Although this study brings some clarifications on the link between the governance mechanisms and performance in microfinance, several governance mechanisms remain unexplored such as CEO duality, graduate board members, international directors, ownership structure. Thus, it seems relevant to conduct more studies in order to learn more about the impact of these governance mechanisms on outreach and sustainability of MFIs not only in the Euro-Mediterranean countries but also in other parts of the world.

\section{References}

Adams, R.; Mehran, H. 2003. Is bank holding company governance different? Economic Policy Review 9(1): 123-142.

Almendariaz de Aghion, B.; Morduch, J. 2000. Microfinance beyond group lending, Economics of Transition 8(2): 401-420.

Armendariz de Aghion, B.; Morduch, J. 2005. The economics of microfinance. Cambridge: MIT Press.

Bassem, Ben Soltane 2008. Efficiency of microfinance institutions in Mediterranean: An application of DEA, Transition Studies Review 15(2): 343-354.

Brick, I. E.; Palmon, O.; Wald, J. K. 2006. CEO compensation, director compensation, and firm performance: Evidence of cronyism? Journal of Corporate Finance 12(3): 403-423.

Byrd, J.; Fraser, D.; Lee, D.; Williams, T. 2001. Financial crises, natural selection and governance structure: Evidence from the thrift crisis. Working paper, Texas A\&M University.

Campion, A. 1998. Current governance practices of microfinance institutions. Washington, DC: The Microfinance Network.

CGAP. 2006. Good practice guidelines for funders of Micro Finance. Available from Internet: <http://www.cgap.org/gm/ document-1.9.2746/donorguidelines.pdf $>$.

Coles, J. W.; Mc Williams, V. B.; Sen, N. 2001. An examination of the relationship of governance mechanisms to performance, Journal of Management 27(1): 23-50.

Cull, R.; Demigüc-Kunt, A.; Morduch, J. 2007. Financial performance and outreach: A global analysis of lending microbanks, Economic Journal 117(517):107-133.
Dewatripont, M.; Tirole, J. 1994. A theory of debt and equity, diversity of securities and manager-shareholder congruence, Quarterly Journal of Economics 109: 1027-1054.

Easley, D.; O’Hara, M. 1988. Optimal non-profit firms, in Rose-Ackerman, S. (Ed.). Economics of Non-Profit Institutions. New York: Oxford University Press.

Eisenberg, T.; Sundgren, S.; Wells, M. 1998. Larger board size and decreasing firm value in small firms, Journal of Financial Economics 48: 35-54.

Ellis, K. M.; Keys, P. Y. 2003. Stock returns and promotion of workforce diversity. Working Paper, University of Delaware.

Fondas, N.; Sassalos, S. 2000. A different voice in the boardroom: How the presence of women directors affects board influence over management, Global Focus 12: 13-22.

Hartarska, V.; Nadolnyak, D. 2007. Do regulated microfinance institutions achieve better sustainability and outreach? Cross-country evidence, Applied Economics 39(10/12): 1207-1222.

Hartarska, V. 2005. Governance and performance of microfinance organizations in Central and Eastern Europe and the newly independent states, World Development (33): 1627-1643.

Healy, P.; Palepu, K. 2001. Information asymmetry, corporate disclosure, and the capital markets: a review of the empirical disclosure literature, Journal of Accounting and Economics 31: 405-440.

Helms, B. 2006. Access for all: Building inclusive financial systems. Washington: CGAP.

Hermalin, B. E.; Weisbach, M. S. 2003. Board of directors as an endogenously determined institution: a survey of the economic literature, Economic Policy Review 9(1): 7-20.

Houston, J.; James, C. 1995. CEO compensation and bank risk: is compensation in banking structured to promote risk taking? Journal of Monetary Economics 36: 405-431.

Jensen, M. 1993. The modern industrial revolution, exit, and the failure of internal control system, Journal of Finance 48(3): 831-880.

Jensen, M. C.; Meckling, W. H. 1976. Theory of the firm: managerial behaviour, agency costs, and ownership structure, Journal of Financial Economics 3: 305-350.

John, K.; Qian, Y. 2003. Incentive features in CEO compensation in the banking industry, Economic Policy Review 9(1): 109-121.

John, K.; Mehran, H.; Qian, Y. 2004. Regulation, subordinated debt and incentive features of CEO compensation in the banking industry. Available from Internet: $<$ http://ssrn. com/abstract $=497922>$.

John, T. A.; John, K. 1993. Top-management compensation and capital structure, Journal of Finance 48(3): 949-974.

Johnson, S.; Malkamaki, M.; Wanjau, K. 2006. Tackling the 'frontiers' of microfinance in global analysis of leading microbanks, Economic Journal 117(517): 107-133. 
Keasey, K.; Thompson, S.; Write, M. 1997. Corporate governance: Economic and financial issues. Oxford: Oxford University Press.

Kyereboah-Coleman, A. 2006. Corporate board diversity and performance of microfinance institutions: the effect of gender, Studies in Economics and Econometrics 30(3): 19-33.

Kyereboah-Coleman, A.; Biekpe, N. 2005. Corporate governance and the performance of microfinance institutions (MFIs) in Ghana. Working paper, UGBS, Legon.

Labie, M. 2001. Corporate governance in microfinance organizations: A long and winding road, Management Decision 39: 296-301.

Ledgerwood, J. 1999. Microfinance handbook: Sustainable banking with the poor: An institutional and financial perspective. Washington, DC: World Bank.

Lipton, M.; Lorsch, J. W. 1992. A modest proposal for improved corporate governance, Business Lawyer 48: 59-77.

Mak, Y. T.; Yuanto, K. 2003. Board size really matters: Further evidence on the negative relationship between board size and firm value, Pacific-Basin Journal 13: 301-318.

McGuire, P. B. 1999. Policy and regulation for sustainable microfinance: Country experiences in Asia, Journal of International Development 1(5): 717-729.

Mersland, R.; Strøm, O. 2007. Performance and corporate governance in micro-finance institutions. Available from Internet: <http://www.cbr.cam.ac.uk/pdf/microgov.pdf>.
Morduch, J. 2000. The microfinance schism, World Development 26: 783-790.

Navajas, S.; Conning, J.; Gonzalez-Vega, C. 2003. Lending technologies, competition and consolidation in the market for microfinance in Bolivia, Journal of International Development 15(6): 747-770.

Robinson, G.; Dechant, K. 1997. Building a business case for diversity, Academy of Management Executive 11(3): 21-30.

Rock, R.; Otero, M.; Saltzman, S. 1998. Principles and practices of microfinance governance. Available from Internet: $<$ http://www.gdrc.org/icm/govern/govern.pdf $>$.

Sanda, A. U; Mukaila, A. S.; Garba, T. 2003. Corporate governance mechanisms and firm financial performance in Nigeria. Final Report Presented to the Biannual Research Workshop of the AERC, Nairobi, Kenya, 24-29.

Steinwand, D. 2000. A risk management framework for microfinance institutions. GTZ, Financial Systems Development, Eschborn, Germany.

United Nations. 2006. Building inclusive financial sectors for development. Washington: United Nations.

Yermack, D. 1996. Higher market valuation of companies with a small board of directors, Journal of Financial Economics 40(2): 185-221. 